\title{
Genetic and agronomic diversity of Basma tobacco (Nicotiana tabacum L.)
}

\section{landrace in Turkey}

\author{
Ibrahim Saygili ${ }^{(1)}$, Ahmet Kinay ${ }^{(1)}$, Dursun Kurt ${ }^{(2)}$, Nejdet Kandemir ${ }^{(1)}$ \\ (1) Tokat Gaziosmanpaşa University. Faculty of Agriculture. Department of Field Crops. 60250 Tokat (Turkey). E-mail: \\ ibrahimsaygili50@gmail.com \\ (2) Ondokuz Mayıs University. Vocational School of Bafra. 55400 Bafra, Samsun (Turkey).
}

Received 8 September 2020, accepted 14 December 2021, available online 22 December 2021.

This article is distributed under the terms and conditions of the CC-BY License (http://creativecommons.org/licenses/ by/4.0).

Description of the subject. In Turkey Basma tobaccos have been produced as landraces. However, little is known about the genetic and agronomic diversity of the Basma tobacco landrace.

Objectives. The aim of the present study was to determine the genetic variation level in Basma type tobaccos used in TokatErbaa region of Turkey, to evaluate some lines under field conditions for agronomic variations and to find out lines with superior yield and quality characters.

Method. Thirteen simple sequence repeats (SSR) markers were used to determine the genetic diversity among 40 single plants collected from Basma tobacco production areas along with the cultivar Xanthi-2A. Twenty-seven different lines identified by SSR markers and cultivar Xanthi-2A were evaluated under field conditions in three Basma tobacco production areas.

Results. All SSR markers were polymorphic and PIC values of the markers ranged from 0.136 to 0.679 with a total of 43 alleles. There were high levels of variation in agronomic characters investigated. The results of the field evaluations showed that most lines had good agronomic characters and some of them were considerably better in quality than Xanthi-2A. In principal component analysis performed with agronomic characters, the first three components explained $85.4 \%$ of the total variation.

Conclusions. We determined that the lines 5, 7, 16, 19,21 and 26 were promising cultivar candidates with good performance. These lines could be further examined for the aim of registration or could be used for development of superior cultivars.

Keywords. Microsatellites, Solanaceae, non-food products, tobacco industry, cigarettes.

Diversité génétique et agronomique du tabac (Nicotiana tabacum L.) de la variété Basma en Turquie

Description du sujet. En Turquie, les tabacs Basma ont été produits en tant que variétés locales. Cependant, on sait peu de choses sur la diversité génétique et agronomique de la variété locale de tabac Basma.

Objectifs. Le but de la présente étude était de déterminer le niveau de variation génétique des tabacs de type Basma utilisés dans la région de Tokat-Erbaa en Turquie, d'évaluer certaines lignées dans des conditions de terrain pour les variations agronomiques et de découvrir des lignées avec des caractères de rendement et de qualité supérieurs.

Méthode. Treize marqueurs de séquences répétées simples (SSR) ont été utilisés pour déterminer la diversité génétique parmi 40 plantes collectées dans les zones de production de tabac Basma avec le cultivar Xanthi-2A. Vingt-sept lignées différentes identifiées par les marqueurs SSR et le cultivar Xanthi-2A ont été évaluées sous les conditions de terrain dans trois zones de production de tabac Basma.

Résultats. Tous les marqueurs SSR (microsatellites) étaient polymorphes et les valeurs contenues d'information polymorphe (CIP) des marqueurs varient de 0,136 à 0,679 avec un total de 43 allèles. Il y avait des niveaux élevés de variation dans les caractères agronomiques étudiés. Les résultats des évaluations sur le terrain ont montré que la plupart des lignées avaient de bons caractères agronomiques et que certaines d'entre elles étaient considérablement de meilleure qualité que Xanthi-2A. Dans l'analyse en composantes principales réalisée avec les caractères agronomiques, les trois premières composantes ont expliqué $85,4 \%$ de la variation totale.

Conclusions. Nous avons déterminé que les lignées 5, 7, 16, 19, 21 et 26 étaient des candidats-cultivars prometteurs avec de bonnes performances. Ces lignées pourraient être examinées davantage à des fins d'enregistrement ou pourraient être utilisées pour le développement de cultivars supérieurs.

Mots-clés. Microsatellite, Solanaceae, produit non alimentaire, industrie du tabac, cigarette. 


\section{INTRODUCTION}

Virginia, burley and oriental tobaccos are widely used in cigarette production around the world. Virginia and burley are large-leaf tobaccos, and are grown under heavy fertilization and irrigation. In contrast, oriental tobaccos are small-leaf quality type tobaccos grown under rainfed conditions with less fertilization. Basma type tobaccos (Nicotiana tabacum L.), a sub-group in the oriental type, have small- or medium-size leaves, which could be light red or dark yellow in color. Their most important feature in tobacco blends is pleasant aroma. Besides, they have a smooth texture, which could be thin or partly thick. Because of these characteristics, Basma type tobaccos are indispensable for special cigarette blends in tobacco industry (Camas et al., 2009). Turkey is a traditional producer of oriental tobaccos. These tobaccos are grown in production areas of Black Sea and Marmara regions of Turkey. Variation in local varieties grown in these production areas and maintained by farmers is a good resource for tobacco breeding.

Local varieties or landraces are major sources of variation to be used in plant breeding. For an efficient use of landraces directly or as genetic resource, they need to be characterized (Kandemir et al., 2010). Although genetic variations are crucial in plant breeding (Zeba \& Isbat, 2011), genetic mixtures within the production material compromise the yield and quality in agricultural production. Basma type tobacco in Turkey is also produced using landraces containing different genotypes (Kurt et al., 2021). Characterization of landraces reveals the genetic diversity within them, and allows isolation of genotypes with high performance. Implementing a production using isolated specific purelines from Basma tobaccos could boost yield and quality.

DNA markers give information about variation level in a population based on allelic richness, heterozygosity and percentage of polymorphic loci (Avolio et al., 2012). DNA markers have been commonly used in determination of genetic diversity levels in different tobacco populations (Moon et al., 2009a; Moon et al., 2009b; Bindler et al., 2011; Darvishzadeh et al., 2013b). Unless supported with data from agronomic traits, information about the variation at DNA level is not very helpful for the use of germplasm resources in plant breeding (Varshney et al., 2010). The fact that each plant in a landrace could represent a different genotype (Alemayehu \& Parlevliet, 1997) implies that a tremendous effort for field and quality tests is required to determine the performance of individual lines constituting a landrace. Evaluation of hundreds of lines in landraces could hinder a thorough evaluation of them due to small plot sizes and lack of replications, which is a major problem especially for agronomic traits with complex inheritance and high environmental interference. As a result, the lines with superior performance could be missed. DNA markers might help reduce the number of lines from a population systematically through determining and eliminating the identical or closely associated ones (Gross et al., 2012). Less number of lines for a detailed agronomic characterization might allow better performance tests without losing the lines with superior performance (Saygili et al., 2021).

Widening and maintaining the genetic basis is crucial in plant breeding programs in that it serves as the source of new genes to be deployed for development of new varieties. The use of genetic resources in plant breeding depends on their characterization. Darvishzadeh et al. (2013a) characterized the genetic diversity in 100 oriental tobacco genotypes using agro-morphological characters, and found plant heights varying from 70.0 to $198.7 \mathrm{~cm}$, leaf number per plant from 8.7 to 52.0 , leaf widths from 10.7 to $33.3 \mathrm{~cm}$ and leaf lengths from 19.1 to $52.5 \mathrm{~cm}$. Diversity analysis based on morphological characters showed that genotypes were clustered by their geographical distribution and growth parameters. In another study, Kalivas et al. (2016) examined a total of 34 tobacco genotypes, 28 of which were oriental, 5 flue cured virginia and 1 burley, for morphological and molecular markers. They identified genotypes which could be used as parents in future breeding programs. Porkabiri et al. (2019) carried out a morphological characterization study with 25 tobacco genotypes, and reported that leaf width and length parameters were the major determinants of ideal genotype with the highest yield. These results indicate that characterization of various genetic resources could help in widening the genetic basis for plant breeding programs.

Modern tobacco cultivars are based on a few parental lines and their offspring (Yang et al., 2007; Moon et al., 2009a). New genetic resources are needed for the improvement of new tobacco cultivars. Landraces are used in the production of Basma type tobacco in a few regions of Turkey. Different genotypes within landraces used in the production could have important variations that could be used in crop improvement. The aim of the present study was to characterize the genetic variation level in Basma type tobaccos used in TokatErbaa region of Turkey, and to evaluate lines under field conditions to identify ones with superior yield and quality characters.

\section{MATERIALS AND METHODS}

\subsection{Plant material}

Basma type tobacco production areas in Erbaa district of Tokat Province (Figure 1), an area with intense 


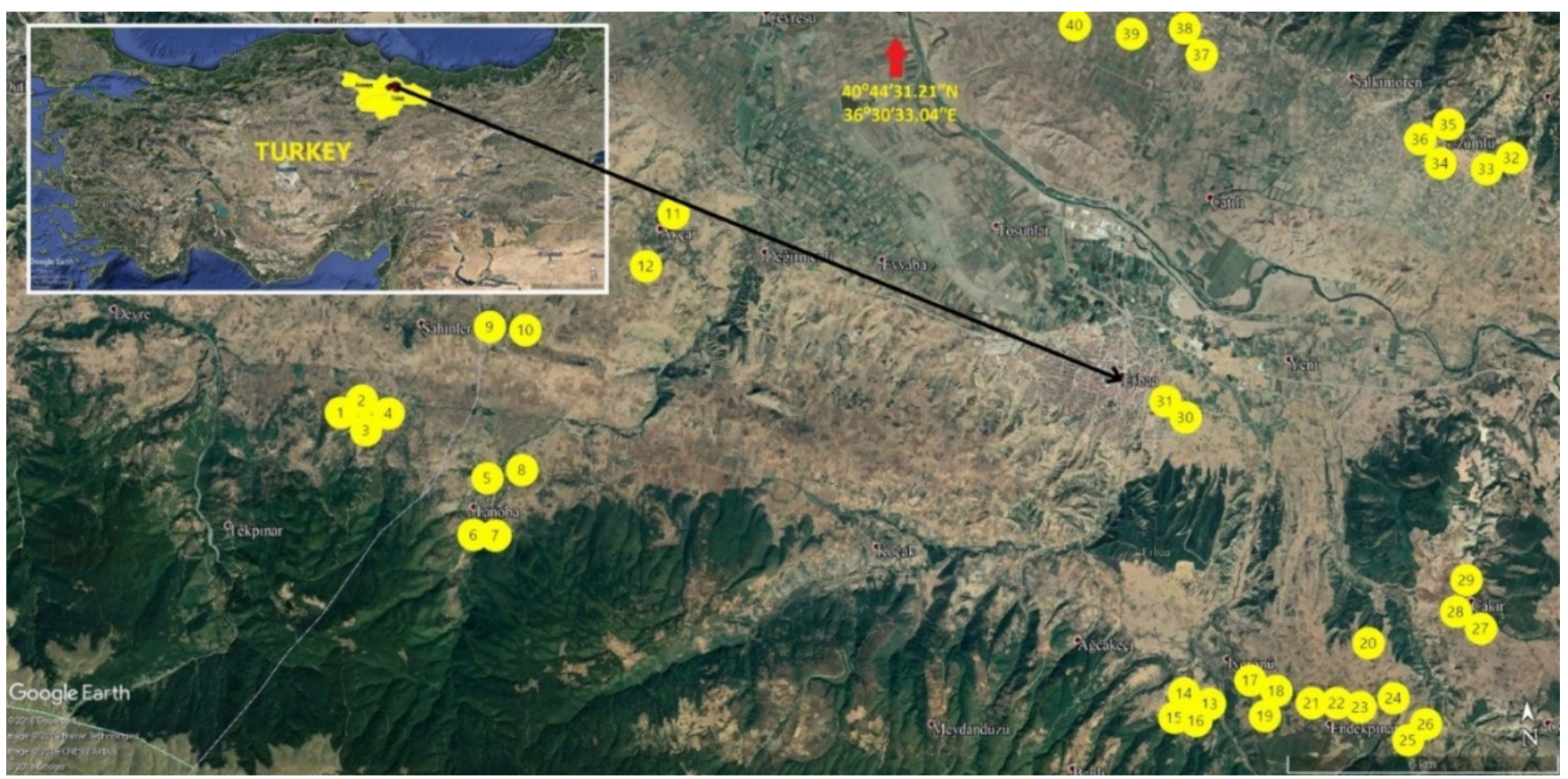

Figure 1. Map of the collection sites of the Basma lines in Tokat province of Turkey - Carte des sites de collecte des lignées Basma dans la province de Tokat en Turquie.

Basma production, were surveyed for plants with different characteristics in flowering period, as well as morphological traits such as plant height, number, form, size and thickness of leaves, undulation of leaf margin and blistering of leaf blade. Selected plants were isolated using a paper bag to prevent outcrossing. Self-fertilized seeds of 40 single plants were harvested after they reached maturity. For DNA isolation, a few seeds were planted for each line and Xanthi-2A cultivar as the standard in peat pots containing peat and perlite (1:1), which were then thinned to a single plant for each line. The plants that were used for DNA extraction were grown, and their self-fertilized seeds produced by isolation of their flowers using paper bags were harvested and used in field trials.

\subsection{DNA isolation and SSR analysis}

DNA was isolated from young seedlings using Turkuaz genomic DNA extraction kit (Keskin et al., 2014). Before the DNA isolation, seedlings with two or three leaves were kept in dark for five days to reduce sugars and phenols which make good quality DNA isolation difficult. Quality of DNA were determined in $1 \%$ agarose gels run in $1 \mathrm{X}$ TBE buffer while quantity of DNA was measured in a spectrophotometer (ThermoBiomate 3) using quartz cuvettes. DNA concentration was adjusted to $50 \mathrm{ng} \cdot \mu \mathrm{l}^{-1}$.

Thirteen simple sequence repeats (SSR) or microsatellite markers with good quality and high polymorphic information content (PIC) value, which measures the polymorphism rate, were used. PT markers were from Bindler et al. (2007) and Bindler et al. (2011), while TM markers were from Tong et al. (2012). Polymerase chain reactions (PCR) were performed according to Kandemir et al. (2010) with some modifications. PCR reactions were conducted in $25 \mu \mathrm{l}$ volume, including $1 \mu \mathrm{l}$ of genomic DNA (50 ng. $\left.\mu \mathrm{l}^{-1}\right), 250 \mathrm{nM}$ each of the two primers, $0.2 \mathrm{mM}$ each of the nucleotides, $10 \mathrm{x}$ PCR buffer and one unit of Taq-DNA polymerase (Bioline). PCR conditions were as follows: $5 \mathrm{~min}$ at $94{ }^{\circ} \mathrm{C}$, then 28 cycles of $30 \mathrm{~s}$ at $94{ }^{\circ} \mathrm{C}, 45 \mathrm{~s}$ at $55-60{ }^{\circ} \mathrm{C}$ depending on the primer, $30 \mathrm{~s}$ at $72^{\circ} \mathrm{C}$, and $5 \mathrm{~min}$ of final extension at $72^{\circ} \mathrm{C}$.

DNA fragments produced in PCR were run on 3 or 5\% MetaPhor agarose gels (Lonza cat no: 50180) in $1 \%$ TBE. PCR products were visualized with ethidium bromide added to gel and were observed using a gel image system (Vilber Lourmat CN-08). PCR products separated in gel were scored using BioCapt v.11.02 software.

For SSR markers, the number of alleles and rare alleles and PIC were determined. The number of alleles is the total number of alleles identified per SSR locus (Darvishzadeh et al., 2013b). A rare allele is the one with less than $5 \%$ of frequency among all alleles of the loci (Moon et al., 2009b). While rare alleles of DNA marker are associated with lower PIC (Leigh et al., 2003), rare alleles of genes could be beneficial and need to be preserved (Whitlock et al., 2016). PIC values for each SSR marker were calculated using the formula: 


$$
\mathrm{PIC}=1-\sum \mathrm{P}_{\mathrm{i}}^{2},
$$

where $\mathrm{P}_{\mathrm{i}}$ is the frequency of $\mathrm{i}^{\text {th }}$ allele (Anderson et al., 1993).

\subsection{Field experiments}

A total of 40 single plants were analyzed using SSR markers and 27 lines which were identified as unique genotypes based on SSR marker polymorphism were selected. These lines were evaluated under field conditions along with cultivar Xanthi-2A. Field trials were conducted in Bağpınar (40 $41^{\circ} 24.27^{\prime \prime} \mathrm{N}$ and $36^{\circ} 39^{\prime} 18.03^{\prime \prime} \mathrm{E}$, altitude $\left.282 \mathrm{~m}\right)$ and Evciler $\left(40^{\circ}\right.$ $36^{\prime} 53.82^{\prime \prime} \mathrm{N}$ and $36^{\circ} 36^{\prime} 16.71$ " $\mathrm{E}$, altitude $494 \mathrm{~m}$, figure 2) villages of Erbaa District of Tokat Province and in Kalkım village $\left(39^{\circ} 48^{\prime} 47.61^{\prime \prime} \mathrm{N}\right.$ and $27^{\circ}$ 13' 08.30" E, altitude $219 \mathrm{~m}$ ) of Yenice District in Çanakkale Province. Climatic data of the experimental areas are given in figure $\mathbf{3}$, and soil analysis results are given in table 1.

Approximately 2,300 seedlings were grown for each line in polystyrene peat pots with float system under greenhouse conditions. The seedlings were transplanted to plots consisting of four rows of $5 \mathrm{~m}$ with $45 \mathrm{~cm}$ distances between rows. Plant spacing on the rows was $10 \mathrm{~cm}$. A randomized complete block experimental design with three replications was used for all trials. The fertilizers $\left(60 \mathrm{~kg} \cdot \mathrm{ha}^{-1} \mathrm{~N}\right.$ and $40 \mathrm{~kg}$. ha $^{-1} \mathrm{P}_{2} \mathrm{O}_{5}$ ) were applied before transplanting of the seedlings. Weeds were controlled manually twice during the growing season. Field trials were conducted

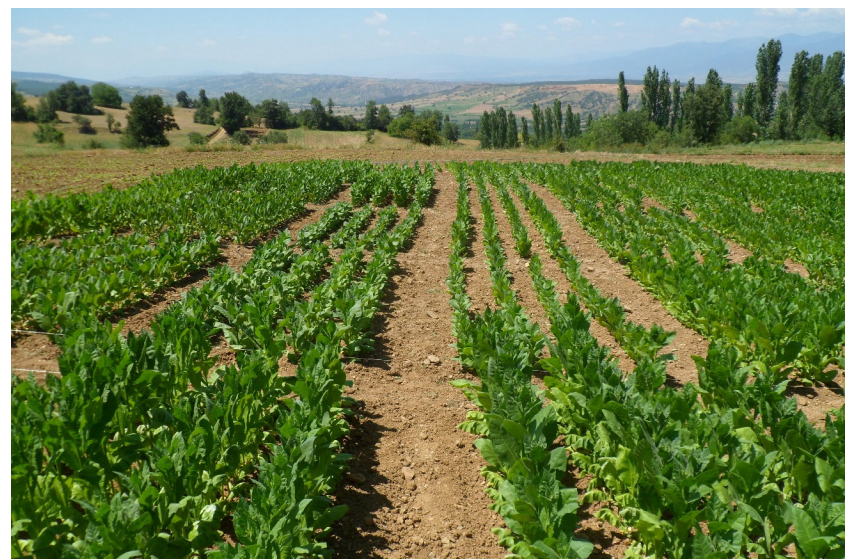

Figure 2. Image of some lines from field trial of Evciler location - Image de quelques lignes d'essais sur le terrain de l'emplacement d'Evciler.

under rainfed conditions without irrigation. Plant height, number of leaves per plant, leaf width and leaf length were measured in 10 plants per plot. Leaves were harvested three times and were dried under the sun. Dried leaf yields were calculated on $17 \%$ moisture basis.

In expertise quality (quality grade index or organoleptic quality index) evaluation of dried leaves, harvests, size, texture, aroma, development of auricle, leaf shape, shape of the leaf tip, thickness of veins, color, brightness of the color, leaf integrity, defects and disease damage were evaluated. Grading was made using these characteristics based on American Grading

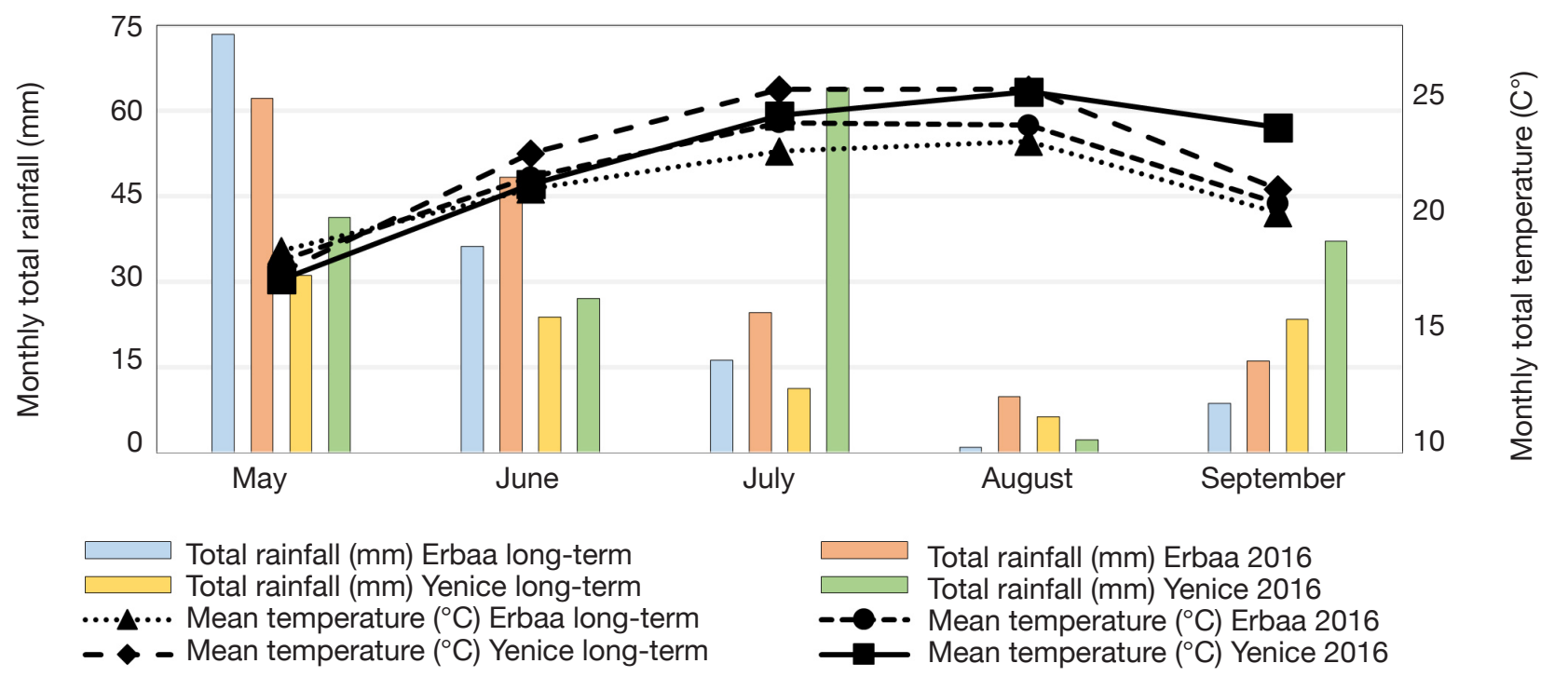

Figure 3. Climatic data for the experimental sites - Données climatiques pour les sites expérimentaux.

For Bağpınar and Evciler sites, data from Erbaa Meteorological Station was used, while for Kalkım data from Yenice Meteorological Station was used - pour les sites de Bağpınar et Evciler, les données de la station météorologique d'Erbaa ont été utilisées, tandis que pour Kalkım, les données de la station météorologique de Yenice ont été utilisées. 
Table 1. Soil characteristics of experimental sites - Caractéristiques du sol des sites expérimentaux.

\begin{tabular}{llll}
\hline & Erbaa & & Yenice \\
\cline { 2 - 3 } & Bağpınar & Evciler & Kalkim \\
\hline Texture & Sandy, clayed loam & Clay & Sandy loam \\
$\mathrm{pH}$ & 7.87 (slightly alkaline) & 6.98 (slightly acidic) & 6.21 (slightly acidic) \\
$\mathrm{EC}\left(\mathrm{dS} \cdot \mathrm{m}^{-1}\right)$ & 0.23 (non-saline) & 1.12 (non-saline) & 0.146 (non-saline) \\
$\mathrm{CaCO}_{3}(\%)$ & 10.66 (moderate) & 3.71 (low) & 0.55 (very low) \\
$\mathrm{Organic} \mathrm{matter}(\%)_{\mathrm{P}_{2} \mathrm{O}}\left(\mathrm{kg} \cdot \mathrm{ha}^{-1}\right)$ & 4.41 (high) & 1.82 (low) & 2.74 (moderate) \\
$\mathrm{K}_{2} \mathrm{O}\left(\mathrm{kg} \cdot \mathrm{ha}^{-1}\right)$ & 35.5 (low) & 93.8 (high) & 41.2 (low) \\
\hline
\end{tabular}

system, and expertise quality score was determined as percentage. Expertise quality score is used to determine the purchasing price of oriental tobacco in Turkey, and is the consensus decision of three tobacco experts (Kinay et al., 2020).

\subsection{Statistical analyses}

A hierarchical cluster (dendrogram) was constructed to represent similarity/diversity among lines based on SSR marker data with the unweighted pair group method using arithmetic mean (UPGMA) algorithm and relationships among the lines were calculated according to Nei (1978) using POPGENE v.1.31 software (Yeh et al., 1997). Data from the field trials were subjected to analysis of variance separately based on randomized complete blocks design using MSTAT-C software (Freed \& Eisensmith, 1986) since the Bartlett variance homogeneity test showed that variances of the trials in locations were not homogeneous. Arcsine transformation was applied to percent values. Duncan multiple range test was used to compare genotype means. Principal component analyses (PCA) were conducted using Minitab V17 software.

\section{RESULTS}

\subsection{Genetic variations}

Thirteen SSR markers were used to determine the genetic diversity among 40 Basma single plants and a registered Basma variety (Xanthi-2A), and to identify genetically identical lines in an effort to reduce the number of the lines to be evaluated in field trials. All 13 markers studied showed polymorphism in our material. Calculated numbers of total and rare alleles, and PIC values are given in table 2. Thirteen SSR markers studied produced a total of 43 alleles (average 3.3 alleles per marker). None of the lines had heterozygous alleles of SSR markers. One marker produced five alleles, while four markers produced four alleles, six markers three alleles and two markers two alleles. Of the 43 total alleles, 10 were produced only in one genotype, and were considered rare alleles. PIC values of the markers ranged from 0.136 to 0.679 .

Based on the dendrogram prepared by SSR marker data, genotypes constituted four groups (Figure 4). It was revealed that lines no. 1,22, 36, 37 and 40 were in fact the same as Xanthi-2A in the first group containing 15 lines. In the same group, lines 2, 13 and 24, lines 4 and 38 , and lines 3 and 39 turned out to be the same genotypes based on the marker data. The second group had lines 5, 10, 12 and 17. The third group had 18 lines. In this group, lines 6 and 8, lines 18 and 20,

Table 2. The results of marker analysis - Les résultats de l'analyse des marqueurs.

\begin{tabular}{lllll}
\hline SSR Marker & $\begin{array}{l}\text { Allele } \\
\text { sizes }\end{array}$ & $\begin{array}{l}\text { Number } \\
\text { of alleles }\end{array}$ & $\begin{array}{l}\text { Rare } \\
\text { alleles }\end{array}$ & PIC \\
\hline PT20242 & $192-208$ & 5 & 3 & 0.574 \\
\hline PT30034 & $212-219$ & 3 & 0 & 0.585 \\
\hline PT30137 & $213-219$ & 2 & 0 & 0.223 \\
\hline PT30274 & $210-219$ & 3 & 1 & 0.381 \\
\hline PT40005 & $241-259$ & 4 & 1 & 0.518 \\
\hline PT53303 & $204-208$ & 3 & 2 & 0.136 \\
\hline PT61056 & $192-204$ & 3 & 1 & 0.326 \\
\hline TM10013 & $141-149$ & 2 & 0 & 0.288 \\
\hline TM10181 & $140-152$ & 4 & 1 & 0.679 \\
\hline TM10211 & $112-124$ & 4 & 1 & 0.549 \\
\hline TM10654 & $112-127$ & 4 & 0 & 0.616 \\
\hline TM10821 & $130-145$ & 3 & 0 & 0.591 \\
\hline TM10976 & $126-135$ & 3 & 0 & 0.553 \\
\hline Total/Avg. & - & 43 & 10 & 0.463 \\
\hline PIC: Polym & & & \\
\hline
\end{tabular}

PIC: Polymorphic information content - contenu d'information sur le polymorphisme. 


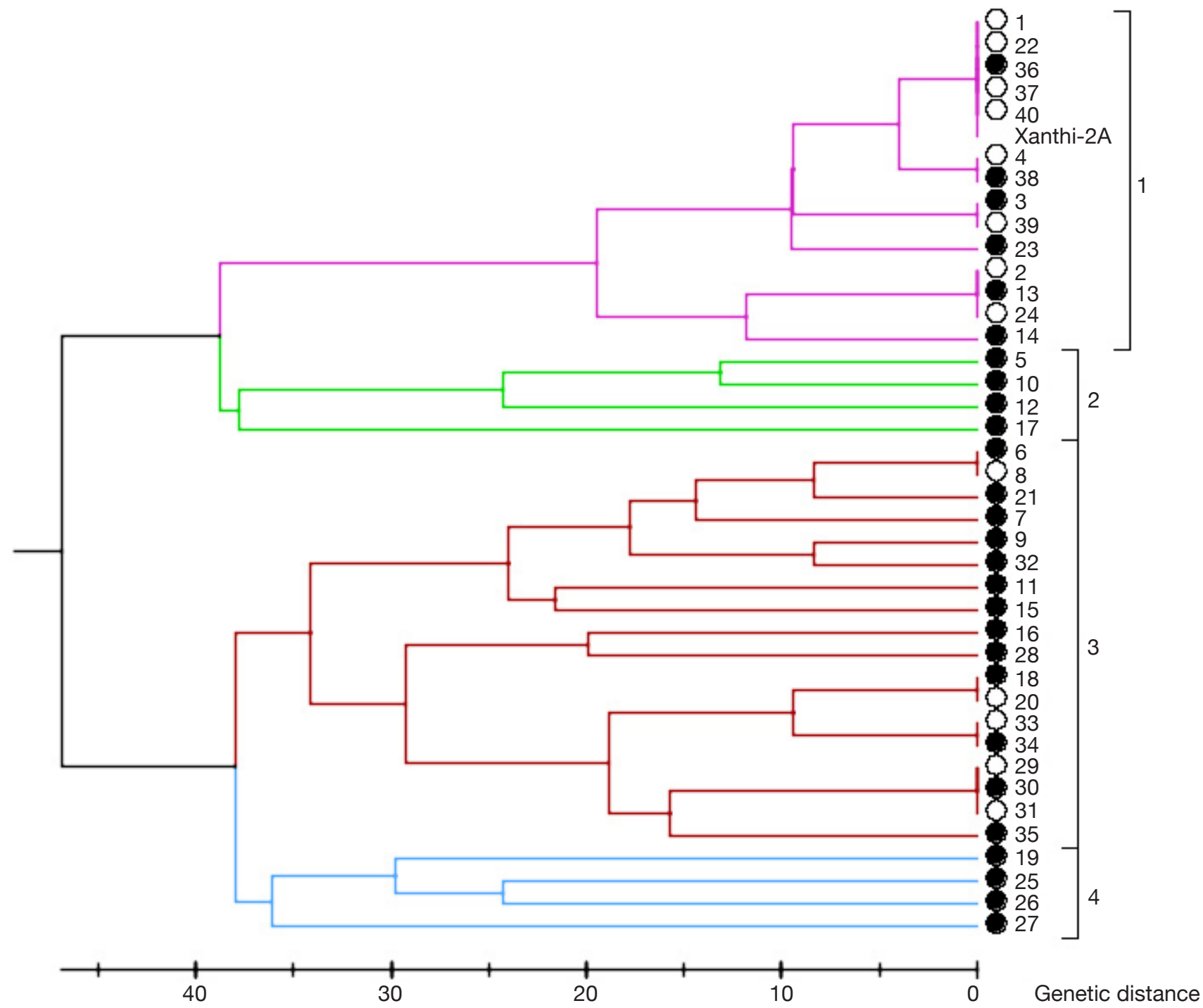

Figure 4. Dendrogram based on SSR marker data - Dendrogramme basé sur les données des marqueurs SSR.

The lines with filled circles were selected for agronomic evaluation based on their genetic diversity — les lignées avec des cercles pleins ont été sélectionnées pour une évaluation agronomique en fonction de leur diversité génétique.

lines 33 and 34 and lines 29,30 and 31 were in fact identical genotypes. The fourth group had lines 19, 25 , 26 and 27 . As result, 13 out of 40 lines examined were identical with another line. Thus, of the 40 genotypes selected, 13 were redundant. In other words, out of 40 lines, 27 differed in at least one SSR allele and these lines were selected for agronomic evaluations.

\subsection{Agronomic variations}

Agronomic characterization of local varieties should be performed with reference to registered varieties. Identification of a line that is superior to any character over the registered varieties indicates that the population carries important alleles. Twenty-seven unique lines identified based on SSR markers and cultivar Xanthi2A were evaluated under field trials in three locations and the data are given in table 3 .

Significant differences were found among the genotypes for plant height in all locations $(p<0.01)$. Based on the averages of all locations, plant height of the genotypes varied from $84.8 \mathrm{~cm}$ (line 28) to $139.6 \mathrm{~cm}$ (line 5). It was observed that all lines except for 3, 17, 28 and 32 were taller than Xanthi-2A. A difference of $54.8 \mathrm{~cm}$ between the lines with the highest and lowest plant height might indicated a high level of variation among the lines for this trait.

Leaf numbers of the genotypes ranged between 23.3 (line 28) and 36.00 (line 5). Lines no 5 (36.0), 16 (34.1) and 10 (33.5) had considerably more leaves 
|

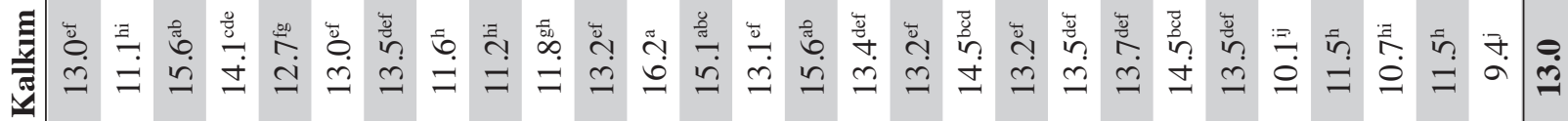

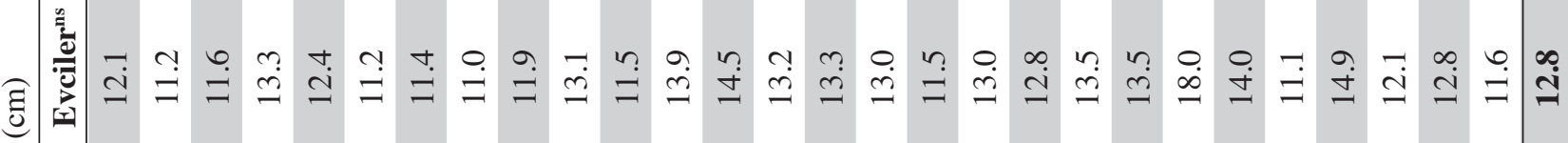

昰

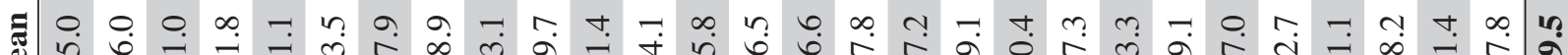

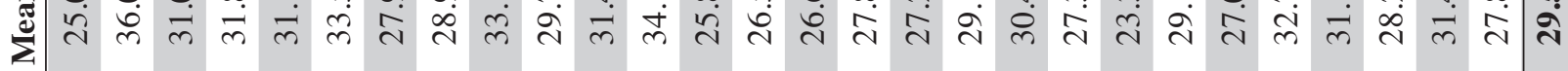

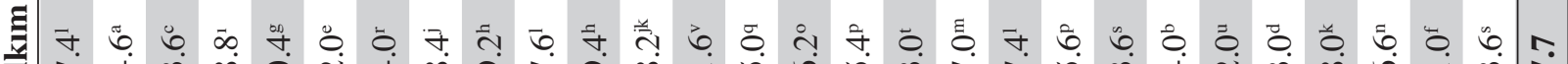

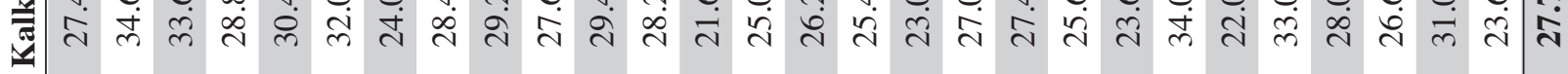

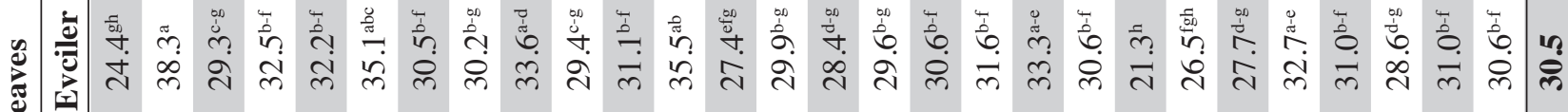

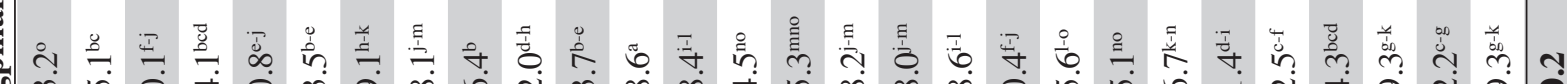

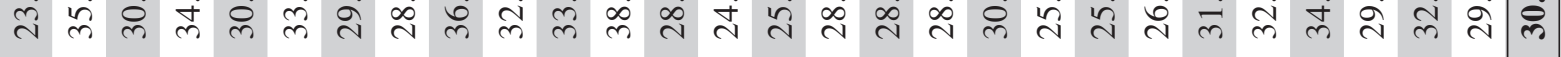

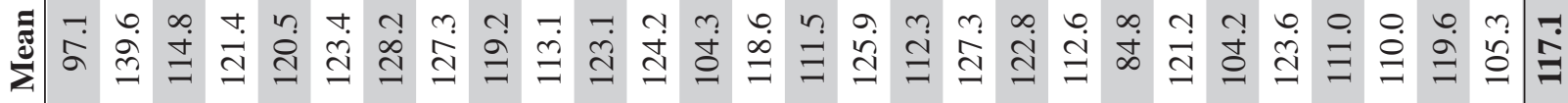

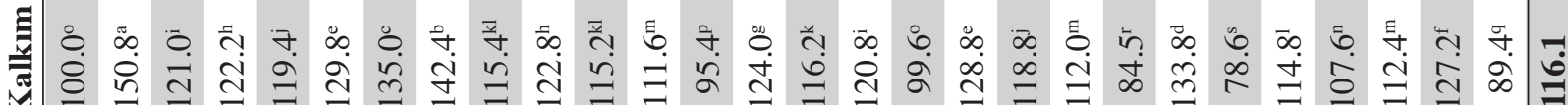

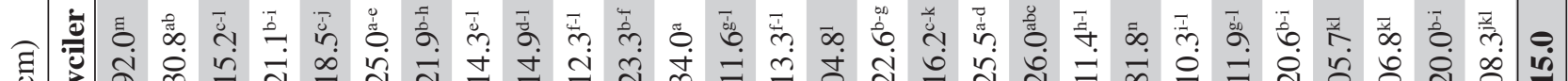
氖兽

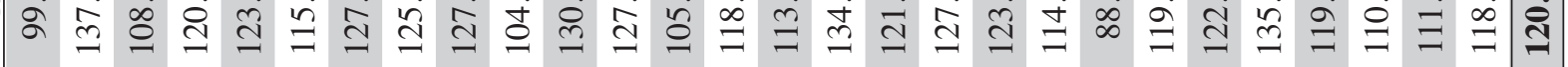




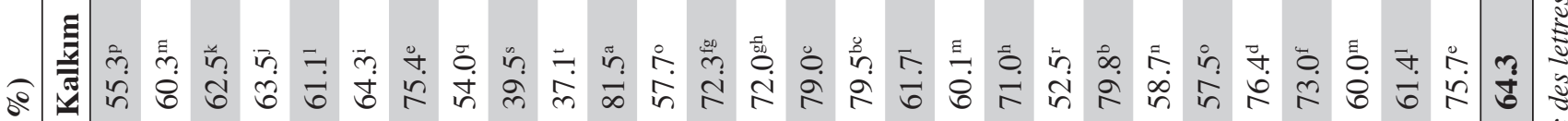
要

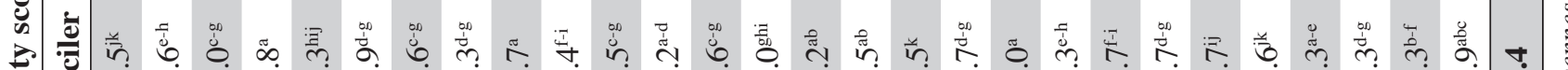

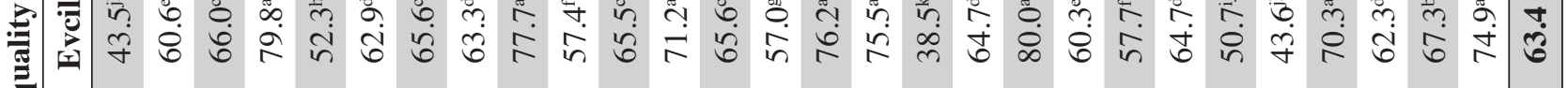
焉

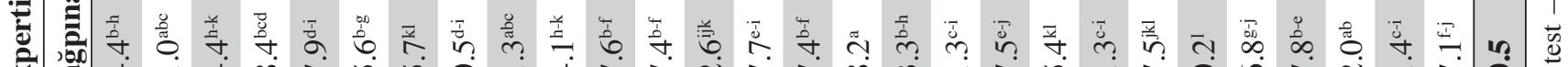

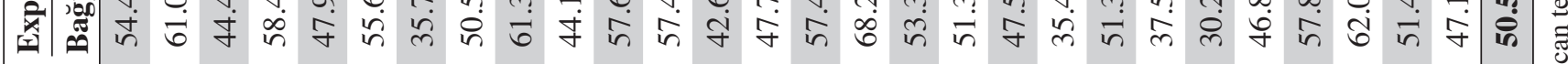

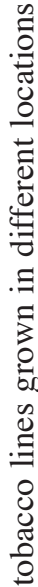
:

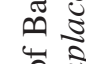
|

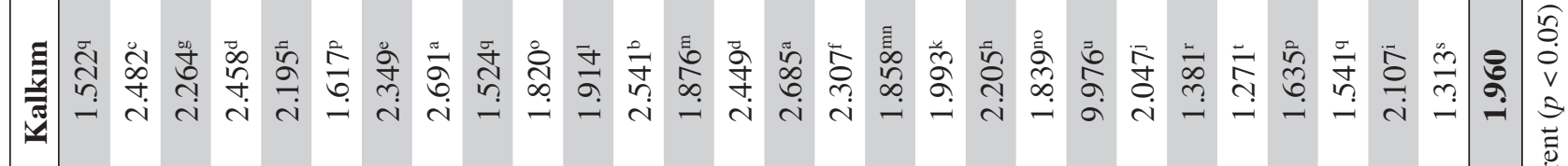



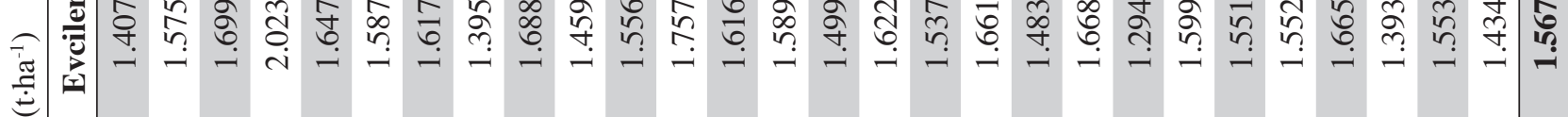

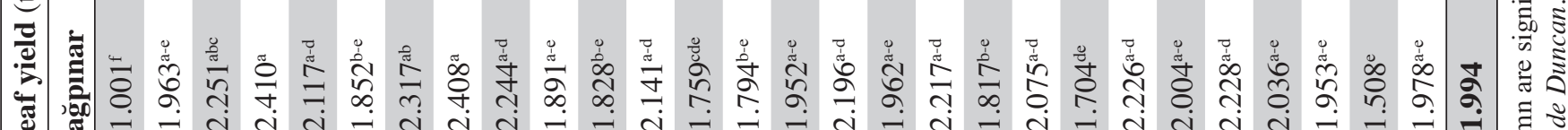

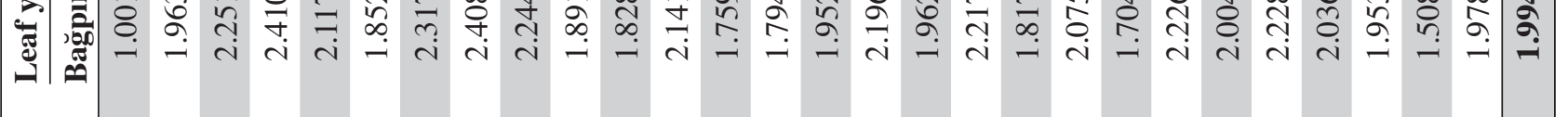

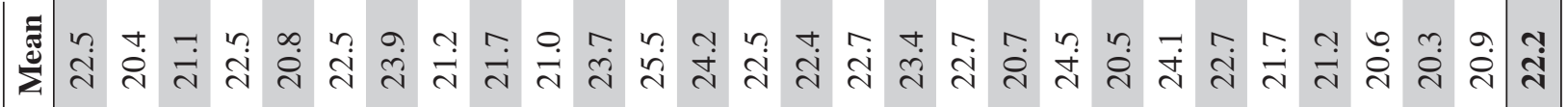
专 竞 
than Xanthi-2A (27.8). Leaf width varied from $10.6 \mathrm{~cm}$ (line 34) to $15.8 \mathrm{~cm}$ (line 30) and the average of all genotypes was $12.9 \mathrm{~cm}$. All lines except for line 34 had larger leaves than that of Xanthi-2A. Leaf length varied between $20.3 \mathrm{~cm}$ (line 38 ) and $25.5 \mathrm{~cm}$ (line 16), and the average was $22.2 \mathrm{~cm}$. All lines but lines 5, 9, 26, 36 and 39 had longer leaves compared to Xanthi-2A.

Dried leaf yield of the lines showed a large variation ranging from $1.310 \mathrm{t} \cdot \mathrm{ha}^{-1}$ (line 3) to $2.023 \mathrm{t} \cdot \mathrm{ha}^{-1}$ (line 7) (average of all lines $1.843 \mathrm{t} \cdot \mathrm{ha}^{-1}$ ). All lines except for 3 and 28 had yields higher than Xanthi-2A.

Expertise quality score is a percentage value that represents the organoleptic evaluation by tobacco experts. It considers characteristics such as the color, aroma and strength of dried tobacco leaves. Expertise quality score of the genotypes varied between $46.1 \%$ (line 32) and $74.4 \%$ (line 21). Cultivar Xanthi-2A has an expertise quality score of $65.9 \%$. Lines 19 (70.9\%) and $21(74.4 \%)$ had considerably higher expertise quality scores compared to cultivar Xanthi-2A. In addition, lines 26, 35, 7 and 15 had higher quality scores than Xanthi-2A.

PCA was carried out to estimate the relative importance of the characters examined and their contribution to the total variance and to show the agronomic diversity among the 27 lines. The first three components whose Eigen value was $\geq 1$ (Hagenblad et al., 2019) constituted $85.4 \%$ of the total variance. The first principal component (PC) explained $38.7 \%$ of the variance. Plant height, leaf number and dried leaf yields had the main contribution to the first PC. PC2 explained $30.1 \%$ of the variance. Most of this variance was constituted by leaf width and length (Figure 5). The third PC, which explained $16.6 \%$ of the variation, had high loading from expertise quality score.

Score plot illustrates the evaluation of lines based on all studied agronomic traits (Figure 6). Cultivar Xanthi-2A and lines 3, 28, 17, 30, 16, 5, 34, 38 and 36

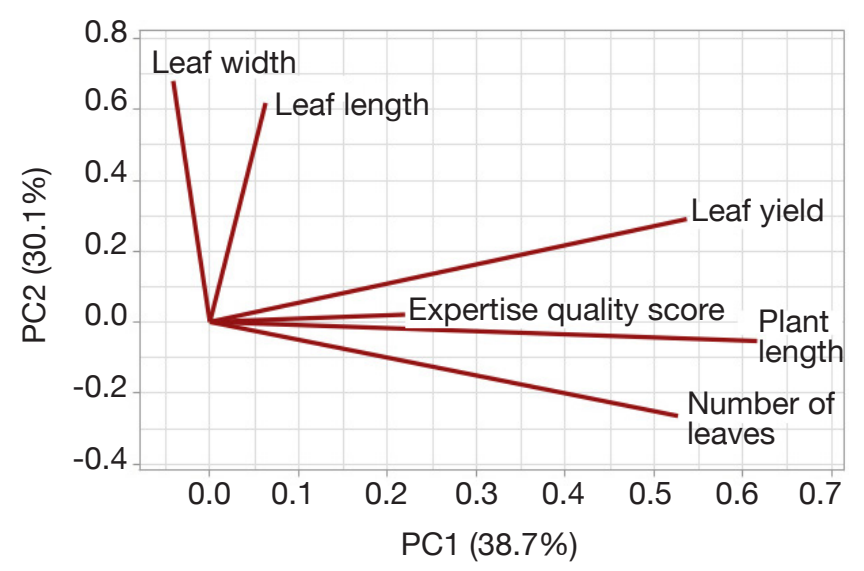

Figure 5. Loading plots for six agronomic traits - Parcelles de chargement pour six caractères agronomiques.

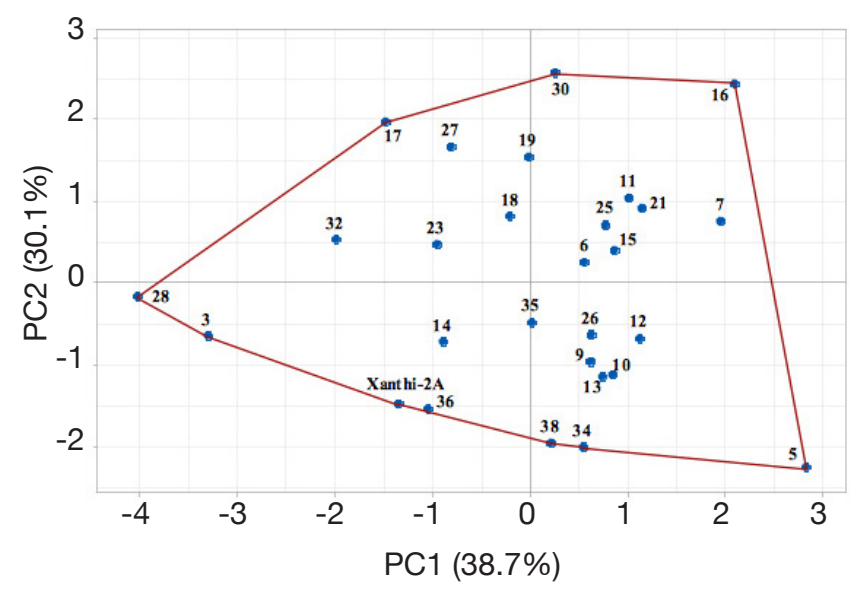

Figure 6. Score plots of Basma tobacco lines - Score plots des lignées de tabac Basma.

are located on the corners of the polygon. These lines on the corners are the most responsive ones (Yan et al., 2000; Hagos \& Abay, 2013). Line 3 had the lowest dried leaf yield, while line 5 had the highest plant height and leaf number, line 16 had the longest leaves, line 28 had the shortest plant and lowest leaf number, line 30 had the highest leaf width, line 34 had the lowest leaf width, and line 38 had the shortest leaves. Line 17 which did not have the highest or lowest value for any character but was on the corner of the polygon had acceptable or higher than the average values for all characters.

\section{DISCUSSION}

All markers studied had polymorphism among the lines. High polymorphism rate is possibly due to the fact that SSR markers used in the present study were selected among highly polymorphic ones reported in previous studies (Moon et al., 2009a; Moon et al., 2009b; Tong et al., 2012). We already showed their high polymorphism rates in another study of our group (Saygili et al., 2020). Average allele number in the present study (3.3) was somewhat lower than 6.8 reported by Fricano et al. (2012) who evaluated many different tobacco types. However, our average allele number was higher than 2.7 reported by Darvishzadeh et al. (2013a) who studied 100 tobacco genotypes of only one type, i.e., oriental and semi-oriental type. Average PIC value determined in the present study (0.463) was higher than the one reported by Davalieva et al. (2010), but lower than the one reported by Darvishzadeh et al. (2013a). However, compared to the results from relatively limited number of studies about tobacco genetic diversity (Yang et al., 2007; Davalieva et al., 2010; Darvishzadeh et al., 2013a), the variation level observed in our study could be regarded high for a local tobacco variety from a limited area. 
Dendrogram generated by SSR data with 40 lines studied revealed that 13 of the lines were identical. In other words, 27 Basma lines that were different for at least one allele of the 13 SSR markers were identified. The lines 1, 22, 36, 37 and 40 in the dendrogram which were collected from fields in four somewhat distant locations (Figure 1) were identical with Xanthi-2A cultivar. Xanthi-2A is a foreign cultivar, and was introduced into the region by tobacco supplier companies. It has been grown in the region for some time. Thus, our findings showed that this cultivar has spread throughout the region. Likewise, using DNA markers, Darvishzadeh et al. (2013a) revealed that one genotype from Iran was very similar to a foreign genotype from Russia. SSRs are reliable (Guney et al., 2018) and reproducible DNA markers (Darvishzadeh et al., 2011), and they allow identification and discarding of genetically identical lines within populations, or identification of lines genetically distant from others to be evaluated in field trials for more extensive tests. Eliminating the identical lines is a necessity for using the strong experimental designs with larger plots and replications which can handle only limited number of lines.

Plant height of the lines had a wide variation (84.8$139.6 \mathrm{~cm})$. Most lines were taller than Xanthi-2A $(117.1 \mathrm{~cm})$ grown in the region, and this finding might indicate that the farmers have favored these lines and multiplied their seeds since longer plants are preferred in Basma tobacco production. Indeed, longer plants have more leaves, and consequently their yields are higher (Kurt et al., 2020). Besides, hand-harvesting of Basma tobaccos is more difficult in shorter plants. Identification of lines with greater plant height could be useful in future tobacco breeding programs aiming to improve leaf yields and ease of harvesting.

Leaf number has always been important in oriental tobaccos which have smaller leaves compared to the tobaccos with large leaf blades such as virginia and burley. Variation in leaf number among the Basma tobacco lines in the present study (23.3-36.0) could make an important contribution to the breeding of oriental tobaccos. Larger leaf size is associated with poor quality in oriental tobaccos (Kurt et al., 2020). Therefore, improving leaf yields should focus on increasing the number of leaves. However, in conditions with shorter growing periods, higher number of leaves in a plant could be undesirable since it could delay harvests (Wolf, 1949). Therefore, the variation observed among these lines could be used to increase the leaf number, a major yield component, in oriental tobaccos.

Variations in local varieties that adapt to the region where they are grown are an important source for plant breeding through single plant selections among them. All lines except for 3 and 28 had higher average leaf yields than Xanthi-2A. These results indicated that there are some cultivar candidates among the lines with good yield potential. These lines could be registered and used directly as commercial varieties or used in future tobacco breeding programs. The lines 5, 7, 16, $17,19,21$ and 26 are promising cultivar candidates with superior yield characters as well as with satisfactory quality traits.

Oriental tobaccos have better quality characteristics compared to virginia and burley tobaccos (Kinay et al., 2020). Quality characteristics of Basma tobaccos, a sub-group in the oriental type, are even higher. The $37.6 \%$ difference between the lowest and highest expertise quality scores indicated the wide variation among the lines. Variations in this major quality trait of Basma tobaccos could be harnessed as a tobacco genetic resource. Local varieties have relatively high genetic variation, ease of hybridization and less problems from undesirable genes which could interfere with crop quality. Thus, use of local varieties in oriental tobaccos could increase the success of plant breeding efforts in this crop for which both yield and quality are essential.

The first three PC explained $85.4 \%$ of the variation. The number of leaves, plant height and leaf yield were the characters that made up the major part of variation. Large variation in these characters is an expected result since Basma tobacco producers prefer high yielding, tall plants with more leaves for the ease of harvest. The finding that the variations of local varieties are higher for agronomic characters which farmers consider most was also reported by Zakova \& Benkova (2006) and Yadav et al. (2018) in landraces of barley, a selfpollinating crop like tobacco.

In deciding the lines to be further examined as cultivar candidates, they should be evaluated considering all characters. Sabaghnia et al. (2008) mentioned that PCA facilitates the identification of superior genotypes and the cultivar recommendation. The lines that appeared in the corners of the score plot in the present study were the lines with the lowest or highest values for the studied characters except for the quality traits. The results from the field studies showed that lines selected from local Basma tobacco population had better agronomic characters than a registered cultivar. These lines could be further examined in multilocational trials for the aim of registration or could be used as parents for the development of superior cultivars.

\section{CONCLUSIONS}

In the present study, genetic, agronomic and quality characteristics of lines selected from Basma tobacco population in Tokat-Erbaa area, one of the few 
growing areas in the world for this type of tobacco, were studied. Characterization of lines with high yield and satisfactory quality characteristics from Basma local variety which could be used directly in tobacco production or in further tobacco breeding programs was the major outcome of the present study. These lines are now maintained as single plants with data about their characteristics, and are available for the use of plant breeders.

\section{Acknowledgements}

We are grateful to Republic of Turkey Tobacco and Alcohol Market Regulatory Authority (TAPDK) for providing the fund for this research work.

\section{Bibliography}

Alemayehu F. \& Parlevliet J.E., 1997. Variation between and within Ethiopian barley landraces. Euphytica, 94, 183-189, doi.org/10.1023/A:1002946004268

Anderson J.A. et al., 1993. Optimizing parental selection for genetic linkage maps. Genome, 36, 181-186, doi. org/10.1139/g93-024

Avolio M.L., Beaulieu J.M., Lo E.Y. \& Smith M.D. 2012. Measuring genetic diversity in ecological studies. Plant Ecol., 213, 1105-1115, doi.org/10.1007/s11258-0120069-6

Bindler G. et al., 2007. A microsatellite marker-based linkage map of tobacco. Theor. Appl. Genet., 114, 341349, doi.org/10.1007/s00122-006-0437-5

Bindler G. et al., 2011. A high-density genetic map of tobacco (Nicotiana tabacum L.) obtained from large scale microsatellite marker development. Theor. Appl. Genet., 123, 219-230, doi.org/10.1007/s00122-0111578-8

Camas N., Karaali H., Caliskan O. \& Kurt D., 2009. Determination the yield and yield components of Basma tobacco cultivars and accessions under Gumushacikoy conditions. In: Proceedings of VIII. Turkey Field Crops Congress, 19-22 October, 2009, Hatay, Turkey, 247-250.

Darvishzadeh R., Alavi S.R. \& Sarafi A., 2011. Genetic variability for chlorine concentration in oriental tobacco genotypes. Arch. Agron. Soil Sci., 57, 167-177, doi. org/10.1080/03650340903286414

Darvishzadeh R. et al., 2013a. Genetic variation in oriental tobacco (Nicotiana tabacum L.) by agro-morphological traits and simple sequence repeat markers. Rev. Cien. Agron., 44, 347-355, doi.org/10.1590/S180666902013000200018

Darvishzadeh R. et al., 2013b. Study on genetic diversity among Iranian water pipe's tobacco (Nicotiana spp.) varieties by using simple sequence repeat markers. Bulg. J. Agric. Sci., 19, 557-562.

Davalieva K. et al., 2010. Genetic variability of Macedonian tobacco varieties determined by microsatellite marker analysis. Diversity, 2, 439-449, doi.org/10.3390/ d2040439

Freed R. \& Eisensmith S.P., 1986. MSTAT - Statistical Software for Agronomists, https://msu.edu/ freed/disks. htm, (27 December 2019).

Fricano A. et al., 2012. Molecular diversity, population structure, and linkage disequilibrium in a worldwide collection of tobacco (Nicotiana tabacum L.) germplasm. BMC Genet., 13, 1-18, doi.org/10.1186/1471-2156-13-18

Gross B. et al., 2012. Identification of "duplicate" accessions within the USDA-ARS national plant germplasm system Malus collection. J. Am. Soc. Hortic. Sci., 137, 333-342, doi.org/10.21273/JASHS.137.5.333

Guney M. et al., 2018. Characterization of hawthorn (Crataegus spp.) genotypes by SSR markers. Physiol. Mol. Biol. Plants, 24, 1221-1230, doi.org/10.1007/ s12298-018-0604-6

Hagenblad J., Leino M.W., Afonso G.H. \& Morales D.A., 2019. Morphological and genetic characterization of barley (Hordeum vulgare L.) landraces in the Canary Islands. Genet. Resour. Crop Evol., 66, 465-480, doi. org/10.1007/s10722-018-0726-2

Hagos G. \& Abay F., 2013. AMMI and GGE biplot analysis of bread wheat genotypes in the Northern part of Ethiopia. J. Plant Breed. Genet., 1, 12-18.

Kalivas A. et al., 2016. Genetic diversity and structure of tobacco in Greece on the basis of morphological and microsatellite markers. Crop Sci., 56, 2652-2662, doi:10.2135/cropsci2015.11.0724

Kandemir N., Yildirim A. \& Gunduz R., 2010. Determining the levels of genetic variation using SSR markers in three Turkish barley materials known as Tokak. Turk. J. Agric. For., 34, 17-23, doi:10.3906/tar-0903-22

Keskin A. et al., 2014. First record of Ixodes arboricola (Ixodida: Ixodidae) from Turkey with presence of Candidatus Rickettsia vini (Rickettsiales: Rickettsiaceae). J. Med. Entomol., 51, 864-867, doi. org/10.1603/ME13169

Kinay A., Yilmaz G. \& Kandemir N., 2020. Yield and quality properties of some oriental tobacco (Nicotiana tabacum L.) hybrids. Genetika, 52, 735-750, doi.org/10.2298/ GENSR2002735K

Kurt D., Yilmaz G. \& Kinay A., 2020. Effects of environmental variations on yield of oriental tobaccos. Int. J. Agric. Wildl. Sci., 6, 310-324, doi: 10.24180/ ijaws.680296

Kurt D., Yilmaz G. \& Kinay A., 2021. GE interaction and stability analysis in some Basma type oriental tobacco (Nicotiana tabacum L.) lines. J. Agric. Sci., 27, 312-320, doi: 10.15832/ankutbd.680854

Leigh F. et al., 2003. Assessment of EST-and genomic microsatellite markers for variety discrimination and genetic diversity studies in wheat. Euphytica, 133, 359366.

Moon H.S. et al., 2009a. Changes in genetic diversity of U.S. flue-cured tobacco germplasm over seven decades 
of cultivar development. Crop Sci., 49, 498-508, doi. org/10.2135/cropsci2008.05.0253

Moon H.S. et al., 2009b. Microsatellite-based analysis of tobacco (Nicotiana tabacum L.). Crop Sci., 49, 21492159, doi.org/10.2135/cropsci2009.01.0024.

Nei M., 1978. Estimation of average heterozygosity and genetic distance from a small number of individuals. Genetics, 89, 583-590, doi.org/10.1093/ genetics/89.3.583

Porkabiri Z., Sabaghnia N., Ranjbar R. \& Maleki H.H., 2019. Genetic variation of some tobacco (Nicotiana tabacum L.) genotypes by morphological traits. Sci. Agric. Bohemica, 50, 1-7, doi.org/10.2478/sab-20190001

Sabaghnia N., Dehghani H. \& Sabaghpour S.H., 2008. Graphic analysis of genotype by environment interaction for lentil yield in Iran. Agron. J., 100, 760-764, doi. org/10.2134/agronj2006.0282

Saygili I., Kinay A. \& Kandemir N., 2020. Determination of an SSR marker set to distinguish genotypes of different tobacco classes. J. Agric. Fac. Gaziosmanpasa Univ., 37, 102-108, dx.doi.org/10.13002/jafag4677

Saygili I., Sonmezoglu O.A., Yildirim A. \& Kandemir N., 2021. Genetic variation among selected pure lines from Turkish barley landrace 'Tokak' in yield-related and malting quality traits. Span. J. Agric. Res., 19, e0702, doi.org/10.5424/sjar/2021194-18021

Tong Z. et al., 2012. Large-scale development of microsatellite markers in Nicotiana tabacum and construction of a genetic map of flue-cured tobacco. Plant Breed., 131, 674-680, doi.org/10.1111/j.14390523.2012.01984.x

Varshney R.K. et al., 2010. Features of SNP and SSR diversity in a set of ICARDA barley germplasm collection. Mol. Breed., 26, 229-242, doi.org/10.1007/ s11032-009-9373-9

Whitlock R. et al., 2016. Consequences of in-situ strategies for the conservation of plant genetic diversity. Biol. Conserv., 203, 134-142, doi.org/10.1016/j. biocon.2016.08.006

Wolf F.A. 1949. Turkish or oriental tobacco. Econ. Bot., 3, 32-41, doi.org/10.1007/ BF02859500

Yadav R.K. et al., 2018. Agro-morphological diversity of Nepalese naked barley landraces. Agric. Food Secur., 7, 86, doi.org/10.1186/s40066-018-0238-5

Yan W. et al., 2000. Cultivar evaluation and megaenvironment investigation based on the GGE biplot. Crop Sci., 40, 597-605, doi.org/10.2135/cropsci2000.403597x

Yang B.C. et al., 2007. Assessing the genetic diversity of tobacco germplasm using inter simple sequence repeat and inter- retrotransposon amplification polymorphism markers. Ann.Appl.Biol., 150,393-340, doi.org/10.1111/ j.1744-7348.2007.00139.x

Yeh F.C. et al., 1997. POPGENE - The user-friendly shareware for population genetic analysis, https://sites. ualberta.ca/ fyeh/popgene.html, (26 December 2019).

Zakova M. \& Benkova M., 2006. Characterization of spring barley accessions based on multivariate analysis. Commun. Biometry Crop Sci., 1, 124-34.

Zeba N. \& Isbat M., 2011. Multivariate analysis for yield and yield contributing traits in F0 and F1 generations in tobacco (Nicotiana tabacum). J. Exp. Biosci., 2, 101106.

(40 ref.) 